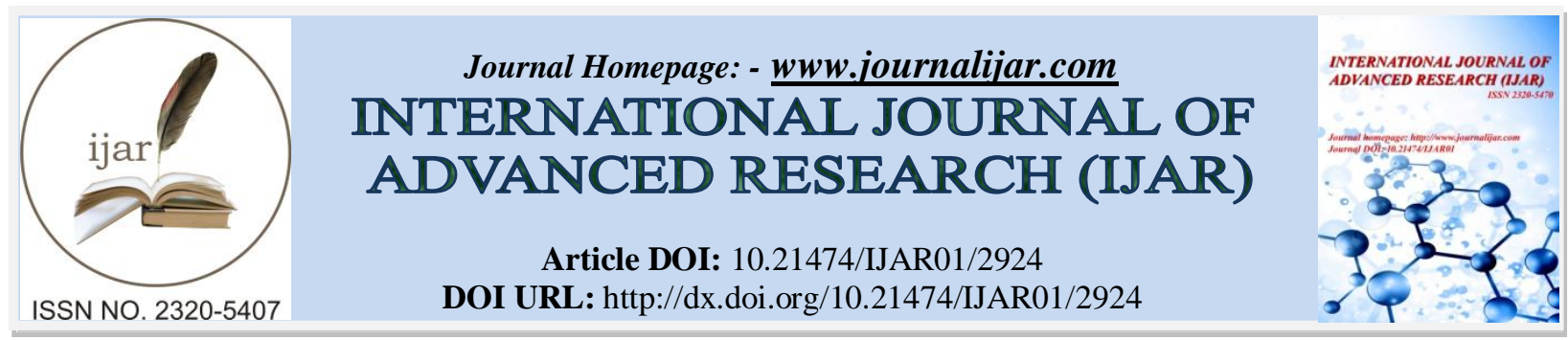

RESEARCH ARTICLE

\title{
THE ROLE OF AUDITING QUALITY IN NARROWING THE EXPECTATIONS GAP IN AUDITING PROFESSION.
}

Hasen Mohamed . A . Albeksh

Department of business administration, Social sciences institute, Kastamonu university. Turkey.

\section{Manuscript Info}

Manuscript History

Received: 24 November 2016

Final Accepted: 25 December 2016

Published: January 2017

Key words:-

Audit Quality, Expectations Gap,

Audit, Performance Gap.

\begin{abstract}
The primary aim of this study is to find out the role of auditing quality in bridging the expectations gap in auditing, Which is considered one of the main factors that has a great effect on the profession of auditing, The study builds on the frameworks developed by Porter (1993), Porter \& Gowthorpe (2004) and Porter et al. (2012). To investigate the influence / importance of the audit expectation gap to the auditing profession, the study also aims to Study and analyze the concept of audit quality and that of expectation Gap and to highlight the role of ways to improve the Audit in order to reduce this discrepancy, has been highlighted on literature and has been used both of the historical approach, inductive approach and descriptive approach to determine the role of auditing quality in bridging the expectations gap in auditing. This study concludes to compliance the auditor with auditing standards effective, auditor independence, importance of the role of professional institutions leads to ensure the reduction of the expectations Audit gap. And, the study recommends to necessary of focus on factors that lead to the emergence of the expectation gap and to raise awareness of the concept of the audit process and to issue audit standards that regulate the profession.
\end{abstract}

Copy Right, IJAR, 2016,. All rights reserved.

\section{Introduction:-}

Accounting and auditing plays an important role in developing and enhancing the economical companies and international works. as they are critical components of any economic enterprise and it plays an important role in contributing to the effective and efficient functioning of business operations, the capital markets, and the economy by adding credibility to financial statements (Lee, Azham \& Kandasamy, 2008). While accounting keeps track of transactions as a basis for providing information about the enterprise through financial reporting to users of the information, audit expresses an opinion on the financial statements whether it presents a true and fair view of the enterprise (Okafor \& Otalor, 2013). These information are considered as the green light for decision makers in their investments and knowing the expected revenues, costs and risks which participate in enhancing the investments whether on the level of the individual or the level of total income. (Al-Khaddash, et al, 2013).

Historically, Humphrey et al. (1992) argue that some hints of "audit expectation gap" (AEG) can be found on the back in the 19th century with the introduction of companies auditing, which appeared to exist for more than 100 years (Flint, 1988). Audit firms have been shaken in the atheist and the twentieth century because of the so-called scandal of Enron, leading to a major audit companies in the world such as the bankruptcy of Arthur Andersen, and 
increasing trust between the audit profession and the gap users of financial statements, which cast a shadow on the job market and review the services and raised doubts in production services in the review of the standards shortcomings audit and regulate the audit profession in general (Benston \& Hartgraves, 2002; Albeksh, 2016).

The auditing profession believes that there is widely criticized and litigation against auditors, this may be due to auditors not meeting the Public's expectations of them on the state of affairs of the audit companies. The auditing profession believes that there is widely criticized and litigation against auditors, this may be due to auditors not meeting the Public's expectations of them on the state of affairs of the audit companies, to investigate the influence / importance of the audit expectation gap to the auditing profession. According to the frameworks developed by (Porter 1993 ; Porter \& Gowthorpe 2004 ; Porter et al. 2012). In a way or another, users of financial information expects that the auditors function to verification of the financial reports to assure safety management's prepared financial statements is free of fraud and is of a high quality. This was a misunderstanding between the perception of auditors for the preparation of financial reports and what the public expects such perceptions are a recurring problem in the literature of accounting and auditing, and usually referred to as the audit expectations gap (Dibia, 2015).

The expectations gap in the audit of the most important issues addressed in accounting thought in the various countries of the world, and despite the many studies on the gap, but it still exists and is widening and require further research and study, in early 1970s, Liggio was first used the word of 'AEG' in the literature, and continues to be debated on until today (Liggio, 1974; Lee et al., 2010). In this context, the study examines the problems associated with the expectation gap in auditing, Which is considered one of the main factors that has a great effect on the profession of auditing, and the audit expectations gap has got with great interest by researchers in the field of auditing and the reason for this is that audit quality as the primary basis have role in narrowing of the expectations gap and then the confidence of investors in the financial and non-financial information, and in this area have tried many of the studies revealed the relationship between narrowing of the expectations gap and that the difference in views among all parties interested in the audit about the concept of expectations gap and the quality of the audit indicates that the crystallization of this concept once and for all as a concept and comprehensive reference, and this requires us to stand on the study of the concept of audit quality and its role in narrowing of the expectations gap in auditing profession.

The researcher followed both of the historical approach to keep track of previous studies that have to relation the study, inductive approach and descriptive approach to determine the expectations gap in the auditing, through extrapolation of studies and research to explaining and describe role of auditing quality in bridging the expectations gap in auditing, even the ideas, relations and the scientific and practical aspects which were included in these researches and studies were descriptive. The method used in this study is considered one of the qualitative descriptive studies non quantitative, which are characterized by giving the researcher an actual and clear theoretical basis in the understanding and interpreting.

It has been divided this paper into six segments. The first segment examines general introduction. The second segment discusses the theoretical framework and approach employed to support this paper where it examines basic concepts: the concept of audit quality and expectations gap and the structure of the components of this gap as well as the manifestations of this gap in the modern audit environment and the reasons that led to the emergence of the expectations gap. The third segment discusses the analysis and evaluation of previous studies in the fields of the expectations gap and Proposed means to narrow the expectations gap in the audit. The fourth segment addressed reflection of the Audit quality on the expectations gap. While the fifth segment addressed the role played by the accounting profession in bridging the gap in auditing of methods and procedures for monitoring the quality of professional performance for audit and activate the role of professional organizations in control of the profession and the issuance of new legislation accommodate the latest changes in the fields of the expectations gap. Finally, the sixth segment contains the results and recommendations which concluded for it this study.

\section{Problem of the Study:-}

\section{Problem of the study in the main question as follow:-}

What is the role of auditing quality in narrowing the expectations gap in auditing?

The variation in understanding the role of auditors and their responsibility in society and the differences and conflicts of milestones and goals between the authors of the reports and financial statements published and users Under this conflict, the role of the external auditor as a neutral party comes only that there is a difference in 
understanding his role, this led to expectations Gap in auditing, which affected to some extent, the confidence of user of financial statement in auditors' performance in the presence of variables in the modern business environment.

\section{Significance of the Study:-}

Which reflected the importance of attention in auditing quality and the extent of their impact on the audit expectations gap in the presence of many variables in the modern business environment and the impact of these variables on the audit profession, derives this study scientific and practical importance in the quality of services provided by the auditor for all related parties in the financial statements that, and represents the scientific importance in drawing academics and research centers Scientific define the concept of the review and its impact on quality narrow the expectations gap to conduct further studies in this area and examine the importance of scientific and practical training for references as a criterion for the quality of the audit and its role in narrowing the expectations gap, and represent the practical relevance in a statement the importance of the quality of the review on factors narrow the expectations gap and the statement of the importance of audit quality According to the interpretation of the relationship between audit and the customer and users of financial statements.

\section{Objectives of the Study:-}

1. Identify the role of auditing quality in narrowing the expectations gap in auditing.

2. Determination of the concepts of audit quality from different entrances, as well as the its importance and objectives and the means used to improve the performance of the audit process.

3. Determination of the concepts of expectations gap, as well as the its importance and objectives.

4. Identify the factors have an impact upon narrowing the audit expectations gap.

\section{The Theoretical Framework:-}

\section{Concept of auditing quality:-}

Audit with the history of commercial and financial events began. If business and financial events occur which, in the modern sense, but there is not necessarily a matter of control. Many people and resources to the case is the definition of a comprehensive review which is expressed in different ways scrutiny (Erdoğan, 2002). It showed several terms in the field of auditing, which is used to describe the quality of the review process, including audit quality and quality control and quality assurance, and each of these terms are private interpretation has emerged, has concluded accountants, Hong Kong Association that quality assurance is an examination of internal and supervision of the audit quality procedures and carried out by the same bureau of quality supervision is intended to external examination by a neutral third party.

So that it has been a lot of important questions about the honesty of the fiscal reports of the auditor, and it has been prevailed a state of mistrust in the auditing profession plus the suspicion of the quality of audit services, and auditing profession had faced more pressures and criticism in purpose of study and assess the quality of the audit, and what increasing these pressures is the absence of the ways to evaluate these qualities (Albeksh, 2016).

DeAngelo (1981a) defines audit quality as the probability that an auditor will discover report a breach in the client's accounting system. The probability of discovering a breach depends on the auditor's technical capabilities and reveals it and the probability of reporting the error depends on the auditor's independence (DeAngelo 1981a; Goldman \& Barlev 1974; Nichols \& Price 1976 ; Adeyemi \& Fagbemi, 2010). The Audit Quality is a management tool used to evaluate, verify, or confirm activities related to quality which serves as the compliance with the professional standards and the contractual terms when carrying out the audit (Syamsuddin, Habbe \& Mediaty, 2014).

Audit quality is a discipline that relies on competent individuals using their experience and applying integrity, objectivity, and skepticism to enable them to make appropriate judgments that are supported by the facts and circumstances of the engagement. The qualities of perseverance and robustness are also important in ensuring that necessary changes are made to the financial statements, or, where such changes are not made, to ensure that the auditor's report is appropriately qualified. In addition to the judgmental nature of aspects of the underlying financial statements, there are a number of factors that make it challenging to describe and evaluate the quality of an audit, including that:-

- The existence, or lack of material misstatements in the audited financial statements provides only a partial insight into audit quality. 
- Audits vary and what is considered to be sufficient appropriate audit evidence to support an audit opinion is, to a degree, judgmental.

- Perspectives on audit quality vary among stakeholders.

- There is limited transparency about the work performed and audit findings (IAASB, 2013; Albeksh, 2016).

Based on the above interpreted audit quality definitions and related aspects, it might be stated that audit quality is a multidimensional construct. In a simplified statement, it can be defined as a level of confirmation between the value audit creates and the expectations to audit of third-party users and audit clients (Vaicekauskas \& Mackevičius, 2014).

\section{The Importance of Auditing Quality:-}

Audit quality is critical for financial markets to function smoothly. And importance of audit quality in the audit process outputs, represented by the auditors' report, which a lot of external users relied upon in the decision-making quality, so the quality of the audit is a common interest to all users of the audit process , including references, companies and administrations, associations and institutions the organization of the profession and creditors. In addition to the above, the adoption of a system to control the quality of the audit can bring many advantages and features, giving proper confirmation that the services performed by the auditors in offices audited, line with professional requirements and generally accepted auditing standards, according to the following:-

- Improve the audit program by following the instructions and guidelines issued in this regard.

- Methods of checking the quality of help to gain new customers for the Office of Audit and maintained.

- A high level of reliability in the functions of the audit means the financial statements are free of material misstatement.

- High quality audit can be considered as part of the owners to control the system from their inability to conduct the direct control of management.

- Quality Audit is one of the important issues that lead to the development of the audit with an advanced level of professional performance to the offices of the audit profession is considered ((DeAngelo 1981a ; Autrey \& Crowley, 2013).

\section{Audit expectations gap:-}

Commission (Cohen, 1978) concluded after studying continued for four years to find out responsibilities of auditors that there are important expectations of the performance of auditors gap and expectations of users of financial statements about the performance of auditors and their responsibilities adversely affects auditing quality, and the Commission found that the responsibility lies with the auditors to reduce that gap.

\section{Definitions:-}

There are many definitions relevant on audit expectation gap, but it revolves around one idea which is the difference or the difference between what he is doing or what can be done by auditors and what should be, or expected to be undertaken by auditors on the basis of society's expectations required of them. (Aljaaidi, 2009). Liggio (1974a) defines it as the difference between the levels of expected performance as envisioned by the independent accountant and by the user of financial statements, through considering whether a gap may exist between what the public expects or needs and what auditors can and should reasonably expect to accomplish.

Porter (1993) carried out an empirical study of the audit expectation-performance gap and defined the expectations gap as the gap between society's expectations of auditors and auditors' performance, as perceived by society.

AICPA (1993), the 'audit expectation gap' refers to the difference between what the public and financial statement users believe the responsibilities of auditors to be; and what auditors believe their responsibilities are. While Epstein and Geiger (1994) defined audit expectation gap as: "differences in perceptions, especially regarding assurances provided between users, preparers and auditors".

Lee, Ali \& Bien (2009) defined audit expectation gap "difference between what the public expects from an audit and what the audit profession accepts the audit objective to be." And mentioned that the AEG is "critical to the auditing profession because the greater the unfulfilled expectations from the public, the lower is the credibility, earnings potential and prestige associated with the work of auditors" (Lee, Ali \& Bien 2009). Also, Audit expectation gap was originally defined as the difference between levels of expected performance as envisaged by auditors and users 
of financial reports. and It is the gap between society's expectations of auditors and auditors' performance, as perceived by society (Shaikh \& Talha, 2003).

Through looking at definitions of mentioned above reveals that the expectation gap may refer to the following:-

- Difference in perceptions on actual performance and expected performance of auditors.

- Existence of these perceptional differences in auditors, accountants or users of financial statements and the society independently and also comparatively.

- The focus of comparative analysis of audit expectation gap is attempted by considering accountants and auditors, the perceptions of society and auditors, investors and auditors (Salehi, 2011).

\section{The structure of components the expectations gap in auditing:-}

Some studies confirm that should blame for auditors because they not meeting users' expectations. Auditors had long been asked to detect errors or frauds. To a large extent, the profession's refusal of performing the fraud detection duties had fueled the 'expectation gap. and confirms that the 'expectation gap' is an outcome of the contradiction of minimum government regulation and the profession's self-regulation, especially, the profession's over-protection of self-interest which has widened the 'expectation gap (Lin \& Chen, 2004).

To knowledge of structure of the expectations gap components will help in reaching a correct understanding of the nature of the gap which helps to narrow it. But as researchers and scholars disagreed gap expectations of access to a specific concept for the gap expectations also differed in determining the structure of the components of the expectations gap (Porter, 1993).

Adopting the title "audit expectation performance gap", she defined it as "the gap between society's expectations of auditors and auditors' performance, as perceived by society". She proposed that the gap comprises two major components, namely:

1. Reasonableness gap: represented a gap between what society expects auditors to achieve and what they can reasonably be expected to accomplish "this coincides approximately with the Cohen Commission's definition of the gap".

2. Performance gap: represented a gap between what society can reasonably expect auditors to accomplish and what society perceives they achieve. This component may be further subdivided into: (a) the deficient standards gap: represented a gap between the responsibilities that can reasonably be expected of auditors and auditors' existing responsibilities as defined by statute and case law, regulations and professional promulgations; and (b) the deficient performance gap: represented a gap between the expected standard of performance of auditors 'existing responsibilities and auditors' performance, as expected and perceived by society.

Additionally, the existence of the expectation gap is due to the shortage of regulations, and to the auditing and accounting standards being founded by the profession; i.e., where users rationally anticipate the auditors to call the users' attention to a special issue, but the profession does not want this since an inadequate standards gap exists (Porter 1993; Koh \& Woo, 1998).

The Canadian Institute of Chartered Accountants (1988) sponsored a study on the public's expectations of audit. The commission developed a detailed audit expectation gap model that analyzed the individual components of the expectation gap into unreasonable expectation, deficient performance and deficient standard (Salehi, 2011). In this aspect, Porter (1993) has provided structure components of the expectations gap in the audit. The structure of the audit expectation-performance gap is depicted in Figure1:- 
Figure 1. Shows structure of the audit expectation-performance gap.

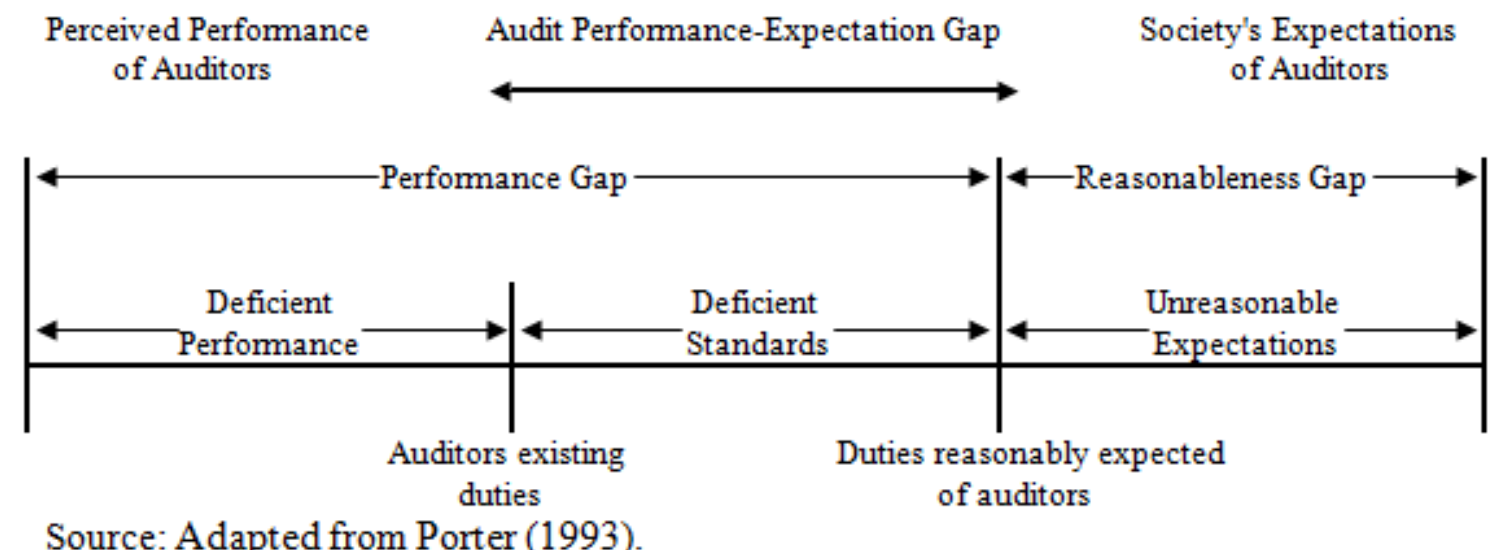

\begin{tabular}{|c|c|c|c|c|}
\hline Perceive & & Societ & s expectation of audit & \\
\hline Performance gap & Standard gap & & Reasonableness ga & \\
\hline Reasonable & Reasonable & & Unreasonable expecta & ons \\
\hline auditor performance & standard & $\begin{array}{l}\text { Over expectation of } \\
\text { audit performance }\end{array}$ & $\begin{array}{l}\text { Over expectation of } \\
\text { standards }\end{array}$ & $\begin{array}{l}\text { Miscommunication of } \\
\text { users }\end{array}$ \\
\hline
\end{tabular}

Source: Adapted from Porter (1993).

The researcher sees that the structure of the components of the expectations gap in the audit presented by Porter has included all the components and elements of the gap and pointed out the reasons that led to the occurrence of the profession, whether these reasons stemming from the audit profession or from outside the profession.

\section{Reasons of audit expectation gap:-}

One of the many issues that involve the accounting profession and the community is exists the expectation gap, researchers have already identified a number of causes for this gap while conducting their research into this issue the most important:-

- The probabilistic nature of auditing.

- The skepticism in the auditor independence.

- The ignorance, naivety, misunderstanding and unreasonable expectations of non-auditors about the audit function.

- The evaluation of audit performance based upon information or data not available to the auditor at the time the audit was completed.

- Insufficiency of self-control system in the audit profession.

- The evolutionary development of audit responsibilities, which creates time lags in responding to changing expectations.

- Decline the quality of professional performance in audit

- Corporate crises which lead to new expectations and accountability requirements.

- The profession attempting to control the direction and outcome of the expectation debate to maintain the status quo.

- $\quad$ lack of legislation and issues professional organization for the profession (Shaikh \& Talha, 2003 ; Salehi, 2007 ; Humphrey, et al, 1993). 
Figure 2. Shows reasons of audit expectation gap:-

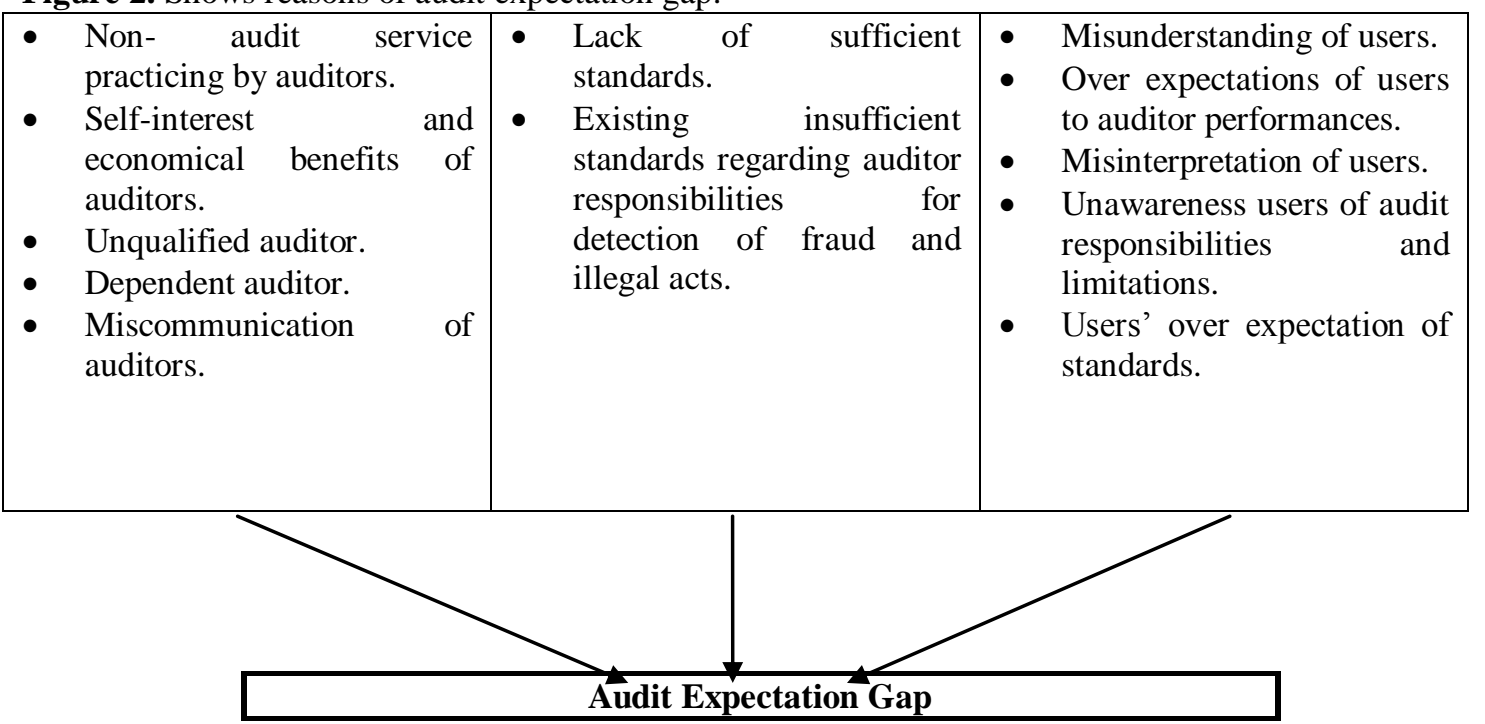

Source: (Salehi, 2007).

\section{The Previous Studies:-}

The growing literature on the AEG can be seen as an indicator that it is a significant problem, which needs additional research. It is not a new research area, there are several of the literature review have focused on the expectations gap and especially during the last two decades. The issue of "gap" between society's expectations of auditors and what auditors expect "or are perceived by society". Extant literature suggests that, while the term AEG was not applied to the gap between society's "or financial statement users" and auditors' expectations of an audit until about 30 years ago, the existence of the gap was recognised more than 100 years ago. Conducting numerous attempts to understand and define the scope and causes of the gap between auditor on the one hand, and the parties used for his services on the other hand, of these studies follows:

Porter (1993) Stated in his empirical study which conducted in New Zealand in 1989 and it aimed to investigate the audit expectation-performance gap to know the reasons and the components of the expectations gap in the return and propose curriculum narrowed through doing a survey to reach this goal, The study enables the duties which constitute the reasonableness, deficient standards and deficient performance components of the gap to be identified. It also provides the means to estimate the relative contribution of the duties to their respective components, and of the components to the overall gap between society's expectations of auditors and auditors' perceived performance. The study concluded to new insights into the structure, composition and extent of the audit expectation-performance gap but, more importantly, it signals a rational, comprehensive approach towards narrowing the gap. If adopted, this should bring society's expectations of auditors and auditors' performance into closer accord and, as a consequence, reduce the criticism and litigation which auditors face today.

There is no doubt that this study has provided a new vision of the details of the constituent tasks for each component of the gap components and the relative contribution of each component to the gap as a whole and this will help to develop an integrated, comprehensive framework to narrow the gap, the study found that narrow the expectations gap will lead to ease the pressure and reduction criticism oriented career.

As Conducted other study to Porter, et al (2012). Audit Expectation-Performance Gap Revisited: Evidence from New Zealand and the United Kingdom. Investigation of changes in the audit expectation-performance gap in New Zealand (NZ) and the United Kingdom (UK) revealed that, between 1989 and 1999, in both countries the reasonableness gap widened as developments in auditing external environment stimulated an increase in society's unreasonable expectations of auditors but the deficient performance gap narrowed as monitoring of auditors' performance resulted in societal perceptions of improved performance. Between 1999 and 2008, in the UK, widespread discussion of the environmental developments and related audit issues, along with more stringent monitoring of auditors' performance, resulted in a narrowing of the reasonableness and deficient performance gaps. In NZ, lacking these factors, these gaps widened. Additionally, changes to auditing standards resulted in some 
'reasonably expected' responsibilities becoming actual responsibilities of auditors and, in both countries, the deficient standards gap narrowed. The research findings illuminate the means by which the audit expectationperformance gap might be narrowed.

While Salehi, (2007; 2011; 2016). Stated in his studies "Reasonableness of Audit Expectation Gap: Possible Approach to Reducing" Which aimed to focus on the reasonableness expectation gap, And "Audit expectation gap: Concept, nature and trace", which aimed to understand the nature and different dimensions of audit expectation gap around the world. In addition to "Quantifying Audit Expectation Gap: A New approach to Measuring Expectation Gap", which aimed to identifying the expectation gap about audit responsibility and quantifying the expectation gap in Iran. The researcher reached to conclusion that for reducing such a gap, a possible way is through increased public awareness of the nature and limitation of audit and the nature and different dimensions of audit expectation gap around the world. And the conclusion that this kind of gap should be reduced by the auditor himself, by improving audit responsibilities, educating various users, and mandating new standards, and that there is an expectation gap between auditors and investors in Iran.

Hassink, et al. (2009). Clarified in their study "Corporate fraud and the audit expectations gap: A study among business managers" which aimed to Assess the importance of a plausibility gap and gap-performance and gap of incomplete standards and this in a specified window companies to defraud, and he clarified that for this to distinguish between all these three elements of the expectations gap, business managers, based on their responsibilities to own about fraud, as banks use as an observer to evaluate the potential differences between the views of business managers and society in general has to be for the participants to be aware and experienced enough on fraud and therefore has been the study of the expectations gap. The findings revealed that there are clear evidence of the existence of great expectations gap in the context of fraud both in terms of the performance of the references or the extent of his commitment to legal texts accepted.

Olowookere, J. K. (2011). Pointed in his study entitled " Stakeholders Perception Of Audit Performance Gap In Nigeria. Which aimed to Search the nature and level of the expectations gap (performance gap) between the auditors and users of financial statements, which sought to determine the presence or absence of differences between the perceptions of financial and reliability of data users and useful for decision-making. The results of the study were the presence of a wide expectation regarding the responsibility of the Auditor gap, which had a negative impact on the credibility of the auditor and the confidence of users of financial statements, The study also showed the media should be more about the responsibilities of the auditor for the financial statements should also clarify the role of the auditor and the observance of quality control measures in the review of institutions' accounts.

The study recommended that it should be the owners of the profession inform the users of financial statements on more responsibilities of auditors as well as raise the educational level of the users of the financial statements, it are tools to limit the expectations gap in the review, also recommended that there should be quality control of audit firms is necessary in order to raise Auditors performance and compliance with recognized standards, also urged the training and continuous improvement of Auditors and the establishment of an independent government body to oversee the implementation of the laws applicable to the review and also recommended expanding the responsibilities of auditors to meet the public's expectations and reducing the missing standards gap through a review of existing auditing standards.

The study dealt with Okafor \& Otalor (2013). under title "narrowing the expectation gap in auditing: The role of the auditing profession. The result shows that the public is ignorant of the duties of the auditor and this lack of knowledge is responsible for unreasonable expectations of the public from auditors. Based on the findings and conclusion, it was recommended that the public need more education on the duties and responsibilities of the auditor, the standard auditor's report should be expanded to include disclaimer clauses clearly showing that it is not a certificate or guarantee of the financial soundness of the audit, it should be clearly stated in the audit report that the auditor is not the compliance officer of the audited company and that the auditor's report should add that the opinion expressed by the auditor should not be construed to mean a guarantee of accuracy of the financial statements .

The study examined Humphrey, et al. (1992). which under title "The Audit Expectation Gap, investigated the expectation gap in both the UK and Spain. Auditors, finance directors and users were asked, inter alia, whether audit firms should not provide NAS to their audit clients. In both countries, the average response was close to neutral for all groups except UK auditors who expressed strong disagreement. 
About this, A survey taken up by $\mathrm{Al}$ qtaish. (2014) in his study the factors affecting in narrowing the audit expectations gap from the viewpoint of the investors in Jordan which aimed to identify the nature of the audit expectations gap and analyzing the factors that may affect in narrowing the audit expectations gap from the viewpoint of the investors in Jordan, mentioned that, the study concluded a set of results including: the factors that influence audit expectations gap, which are: the efficiency of the auditor and his professional care, the auditor's responsibility for the certified accounting numbers, the verification of the auditor on the level of the disclosure in the financial statement, improvement of communication with the users of the financial statements, the auditor's commitment to integrity and honesty, and the independence of the Auditors. It was found that the effect of these factors was high and uneven. The study recommended that the necessity to enhance communication, information and the education of the users of the financial statements on the functions of auditing, responsibilities and duties of the auditor, management responsibilities, and the expansion of the auditor's responsibilities to meet the reasonable expectations, and to adopt the detailed auditor's report to mitigate the audit expectations gap.

\section{Evaluation of the Previous Studies:-}

The litigious environment which in the auditing profession today can be traced to the audit expectation gap and from here there are calls for operates a good monitoring of public opinion and attitudes towards the level of services and assurance provided by the auditors individually and as a profession. Where investors expect and counts begin to uphold a standard of absolute assurance, audit liability inevitably will increase substantially. It is necessary therefore that from both societal and professional perspective that the profession should try to narrow the expectation gap. To achieve this both groups need to become active agents or players for positive change.

These the evaluation are based upon the prior study's results in the field of the expectations gap, and through what the researcher mentioned above about a literature review and a critical and in depth evaluation of previous research about the role of auditing quality in narrowing the expectations gap in auditing profession. The literature has shown that most the studies which addressed the expectations gap of several entrances, it has the impact of a high level for this the gap on auditing profession, studies have focused upon the research in its concept and components and reasons leading to that gap as a plausibility gap and gap-performance and gap of incomplete standards, Other studies have dealt with the impact of factors such as an audit report and the expectations gap, and the role of auditing quality in reducing this gap among auditors and investors. The reasonableness gap widened as developments in auditing external environment stimulated an increase in society's unreasonable expectations of auditors, but the deficient performance gap narrowed as monitoring of auditors' performance resulted in societal perceptions of improved performance. The most study found that narrow the expectations gap will lead to ease the pressure and reduction criticism oriented career. and this will help to develop an integrated, comprehensive framework to limit of risk audit profession.

Last but not least, the common belief that external auditors are able to solve all the problems faced audit profession, while it is a part of the justice system in the audit profession. When the narrow the gap was discussed, researchers recommended that there should be quality control of audit firms in order to raise Auditor's performance and compliance with recognized standards, until be financial reports are reliability for users of financial statements and useful for decision-making, and necessity of vocational rehabilitation of the internal and external auditor. In addition to continuous training of auditors and make courses for auditing companies in the specializations of accounting and financial sciences to reinforce the important role of the commitment to auditing standards effected in audit quality to be an effective prevention from falling in cheating, manipulating, embezzlement and betraying honesty.

\section{Reflection of the Audit quality on the expectations gap:-}

Concept of audit quality is based on that commitment to professional standards issued by international and professional organizations achieve audit quality. Usually focus audit quality programs to these organizations about the extent of commitment audit firms to accepted professional standards (GAAS) own to audit which put in place to ensure minimum audit quality when the implementation of the audit. This concept of quality means that if the auditor's commitment to professional standards for the audit, it will achieve a good level of professional performance quality. The audit quality normally consists of two components: auditor competence and auditor independence. The deterioration in audit quality in a short tenure audit may be due to either lack of competence or loss of independence, while a loss in quality in a long tenure audit is most likely due to a loss of independence (DeAngelo, 1981a; Enofe et al, 2013). 
Auditing standards provide an important foundation supporting audit quality. In particular, the International Standards on Auditing (ISAs) issued by the IAASB describe the auditor's objectives and establish minimum requirements. However, the majority of the requirements in ISAs either provide a framework for the judgments made in an audit or need judgment for them to be properly applied ((IAASB, 2013).

As clarified Porter (1993) the audit expectation-performance gap and defined the expectations gap as the gap between society's expectations of auditors and auditors' performance, as perceived by society.

The quality gap is one a sub-components to the expectations gap in the audit, it has identified its one of the researchers quality gap as "the differences between the expectations of both users and auditors about the quality of performed audit services, and factors of formation and the formation of that quality, "and stressed that the main reason for its existence is to decrease the actual performance of references for auditing standards and quality standards recognized (Carcello, et al, 1992).

And considered decline the quality of professional performance in audit is one of the main reasons for the existence of the expectations gap, So it considered improving the quality of audit services one of the methods to narrow the expectations gap in the audit.

\section{The Role Played by the Accounting Profession in Bridging the Gap in auditing:-}

The accounting profession has recognized that there is the expectation gap as an issue of fundamental relevance that has a great effect on the profession of auditing. It is in the best interest of both the auditing profession from side and the society at large on the other hand, because the gap between society's expectations of auditors and auditors' performance, as perceived by society, the expectation gap in auditing profession be narrowed as much practicable (Ijeoma, 2014).

In 1988, Committee and the Auditing Standards Board in the American Institute of Certified Public Accountants (AICPA) tried to reduce the expectation gap by issuing series of statement of accounting standard. In this aspect, General Accounting Office and the AICPA in 1996 reported that an expectation gap still exists and no empirical evidence was however offered to that effect. Investors and other users of financial statement seek for absolute assurance but the auditing profession has relied on the concept of reasonable assurance. Current auditing standards still reflect material mismanagement focus or financial statement reasonable assurance.

In 1997, Statement on Auditing Standards No. 53 (SAS 53) "the auditors responsibility to detect and report errors and irregularities" which is one of the expectation gap SASs rely on the concept of reasonable assurance. The profession in further attempts to narrow the expectation gap issued new (SASs) statement of Auditing Standards, partly to address public criticism of the auditing profession and partly to increase level of service to audit clients and the public, and No. 82 (SAS 82) replaced one of the Expectation Gap standards. It was intended to provide more explicit guidance for the auditor's consideration of fraud in a financial statement audit.

Also, In 1988, the Auditing Standards Board (ASB) issued a number of pronouncements that have been referred to as the Expectation Gap standards. The intent of these standards was to reduce the gap between public expectations and the perceptions of auditors with respect to auditors' roles and responsibilities in conducting financial statement audits. The Expectation Gap standards were intended to:-

- Address public concerns regarding detection of errors, irregularities and illegal acts.

- Assist auditors in planning more effective audits.

- Improve external auditor communications.

- Improve internal communications for the purposes of the current study, the breach between public expectations and auditors' perceptions of their responsibilities will be referred to as "Expectation Gap" (Specht \& Sandlin, 2011).

And in this regard (Erdoğan, 2012). Clarified that, Training on the audit, the whole exercise consists of checking with the academic knowledge of control theory. It is necessary to establish the cause of development and control theory. Courses in auditing, licensing, education and learning in graduate programs, and this is an important issue is related to a large extent on the quality of education and increase efficiency (Erdoğan Murat, 2012). 
Last but not least, the common belief that auditors are able to solve all the problems faced audit profession, including expectation gap, while they are a part of the justice system in the audit profession. when the independence of the external auditor was discussed, researchers recommended to necessity of auditors commitment to audit and develop their standards on an ongoing basis to ensure the quality of work and narrow expectations in the gap and the need to audit the appointment of auditors with experience and skill to carry out the audit to narrow the expectations gap and pre-planning of the audit process because it ensures the continuation of the process effectively and thus narrow the expectations gap in the audit.

\section{Results:-}

The study reached a number of conclusions, including:-

1. Auditors commitment to standards audit and develop their abilities on an ongoing basis leads to ensure the quality of work and to narrow the expectations gap in the audit.

2. The reasons that led to the emergence of the expectations gap and the reason was in the weakness of auditor independence and the lack of professionalism of the auditor and not the reasonableness of expectations of users of financial statements and lack of clear definition of the role of auditor in the community and inadequate system of self-censorship in the profession and the decline of professional performance and inadequate of financial reporting as well as lack of legislation and issues professional organization for the profession.

3. One of the most important reasons for the expectations gap in the revision auditor independence in doubt. As well as the reasons for the gap of lack of professionalism and lack of reasonable expectations of the profession and the public lack of effective communication and lack of financial reporting.

4. The admission of new clients and continuation of the relationship with a reputable existing customers good reduces the problems and increases to narrow the gap and the commitment of the references standard examination league program sufficiently on the quality of performance raises the audit quality degree and narrow the expectations gap and the commitment of the audit team of accounting and auditing standards narrowing of the expectations gap.

\section{Recommendations:-}

In the light of the results of theoretical studies can provide a range of the following recommendations:-

1. The necessity of Auditors commitment to standards audit and develop their abilities on an ongoing basis to ensure the quality of work and to narrow the expectations gap in the audit.

2. The necessity of focus on the analysis and characterization of the expectations gap in the review, where it is one of the most serious issues facing the auditing profession and effect on audit quality and the decisions of investors.

3. The necessity of professional organizations, associations, scientific inventory of the most important proposals narrow the expectations gap in the review. And work on the application of the best proposals to get on high of audit quality.

4. The necessity of define the beneficiaries of the services of auditing the most important concepts used by the audit profession in order to reduce the size of the expectations of the unacceptable.

5. The necessity of focus on factors that lead to the emergence of the expectations gap and the most important are: uncertainty in the auditor independence and low professional performance and inadequate financial reporting issues, legislation and organization of the profession and not the reasonableness of expectations of beneficiaries and take the necessary measures to eliminate these factors.

\section{Acknowledgement:-}

I would like to thank the anonymous reviewers and Editor in Chief for support of this the paper. I would also like to thank all the respondents who through their active participation in our survey contributed to the achievement of goals set in my work. 


\section{References:-}

1. Al qtaish. H.F. (2014). The Factors Affecting in Narrowing the Audit Expectations Gap from the Viewpoint of the Investors in Jordan. Research journal of finance and accounting Vo 1.5, No.12, 2014.

2. Albeksh, H. M. (2016). Compliance of Auditors to Ethics and Rules of Professional Conduct and Its Impact on Audit Quality. Imperial Journal of Interdisciplinary Research, 2(12).

3. Albeksh, H. M. A. (2016). Factors affecting the independence of the external auditor within the auditing profession. International journal of management and commerce Innovations ISSN 2348-7585(online). vol.4,Issue2,pp-680-689).

4. Albeksh, H. M. A. (2016). The Crisis of the Ethics of Audit Profession: Collapse of Enron Company and the Lessons Learned. Library Journal, 3, e3205.

5. Aljaaidi, K. S. Y. (2009). Reviewing The Audit Expectation Gap Literature from 1974 to 2007.

6. Al-Khaddash, H., Al Nawas, R., \& Ramadan, A. (2013). Factors affecting the quality of auditing: The case of Jordanian commercial banks. International Journal of Business and Social Science, 4(11).

7. American Institute of Certified Public Accountants AICPA. (1993), "Professional Standards", Report, Conclusions and Recommendations, New York, USA.

8. Autrey, R., \& Crowley, R. (2013). The Importance of Audit Quality Standards.

9. Benston, G. J., \& Hartgraves, A. L. (2002). Enron: what happened and what we can learn from it. Journal of Accounting and Public Policy, 21(2), 105-127.

10. Carcello, J. V., Hermanson, R. H., \& McGrath, N. T. (1992). Audit quality attributes: The perceptions of audit partners, preparers, and financial statement users. Auditing, $11(1), 1$.

11. Chye Koh, H., \& Woo, E. S. (1998). The expectation gap in auditing. Managerial Auditing Journal, 13(3), 147154.

12. Cohen Commission. (1978). Report of the Commission on Auditor Reasonability's: Conclusions and Recommendations. New York: American Institute of Certified Public Accounts.

13. DeAngelo, L. E. (1981a). Auditor independence, "low balling," and disclosure regulation. Journal of Accounting\& Economics 3(August): 113-27.

14. Dibia, N. O, (2015). Audit Expectations Gap and Perception of Financial Reporting. International Journal of Managerial Studies and Research (IJMSR) Volume 3, Issue 3, March 2015, PP 23-31.

15. Enofe, A. O., Okunega, C. N., \& Ediae, O. O. (2013). Audit Quality and Auditors Independence in Nigeria: An Empirical Evaluation.

16. Erdoğan Murat,(2012). "VUK-TFRS Geçiş Sürecinde Üniversitelerde Denetim Eğitim ve Öğretim Döngüsü Önerisi ve Web Tabanlı Bir Yazılım ile Denetim Uygulaması" 24. Dünya Sürekli Denetim ve Raporlama Sempozyuти, 3-4 Mayls 2012, Malatya.

17. Erdoğan Murat, (2002). Finansal Muhasebe (Yöneticilerin Karar Verme Aracı Olarak), Beta Basın Yayım Dağıtım A.Ş., Istanbul, 2002 (975-295-131-7).

18. Flint, D. (1988), "Philosophy and principles of auditing", Hampshire: Macmillan Education Ltd.

19. Goldman, A., and B. Barlev. (1974). The auditor-firm conflict of interests: Its implications for independence. The Accounting Review 49(October): 707-18.

20. Hassink, H. F., Bollen, L. H., Meuwissen, R. H., \& de Vries, M. J. (2009). Corporate fraud and the audit expectations gap: A study among business managers. Journal of International Accounting, Auditing and Taxation, 18(2), 85-100.

21. Humphrey, C., Moizer, P., \& Turley, S. (1993). The audit expectations gap in Britain: An empirical investigation. Accounting and Business Research, 23(sup1), 395-411.

22. IAASB (2013). A Framework for Audit Quality, International Auditing and Assurance Standards Board. https://www.ifac.org.

23. Ijeoma, N. B. (2014). Bridging The Expectation Gap In Auditing: The Role Of The Accounting Profession In Nigeria.

24. Lee, T. H., Ali, A. M., \& Bien, D. (2009). Towards an Understanding of the Audit Expectation Gap. ICFAI Journal of Audit Practice, 6(1).

25. Lee, T.H., Ali, A.M., Gleock, J.D., Yap, C.S., Ng, Y.L. and Boonyanet, W. (2010), “The audit expectation gap in Thailand",Southern African Journal of Accountability and AuditingResearch, Vol. 10, pp. 1-17.

26. Lee, T.H; Azham, Md. Ali \& Kandasamy, S. (2008), Towards reducing the audit expectation gap: Possible mission? Accountants Today, pp. 18-22, Feb. Available at: http://www.mia.org.my/at/at/200802/06. PDF. Viewed 8th August, 2011.

27. Liggio CD (1974a). The Expectation Gap: The Accountant's Waterloo. J. Contemp. Bus., 3(3):27-44. 
28. Lin, Z. J., \& Chen, F. (2004). An empirical study of audit 'expectation gap'in the People's Republic of China. International Journal of Auditing, 8(2), 93-115.

29. Nichols, D. R., and K. H. Price. (1976). The auditor-firm conflict: An analysis using concepts of exchange theory. The Accounting Review 51(April): 335-46.

30. Okafor, C. A., \& Otalor, J. I. (2013). Narrowing the Expectation Gap in Auditing: The Role of the Auditing Profession. Research Journal of Finance and Accounting, 4(2), 43-52.

31. Olowookere, J. K. (2011). Stakeholders' Perception of Audit Performance Gap in Nigeria. International Journal of Accounting and Financial Reporting, 1(1), 29.

32. Porter, B. (1993), An empirical study of the audit expectation-performance gap, Accounting and Business Research, Vol. 24,No .93,Winter, pp. 49-68.

33. Porter, B., \& Gowthorpe, C. (2004). Audit expectation-performance gap in the United Kingdom in 1999 and comparison with the Gap in New Zealand in 1989 and in 1999. Institute of Chartered Accountants of Scotland.

34. Porter, B., Ó hÓgartaigh, C., \& Baskerville, R. (2012). Audit Expectation-Performance Gap Revisited: Evidence from New Zealand and the United Kingdom. Part 1: The Gap in New Zealand and the United Kingdom in 2008. International Journal of Auditing, 16(2), 101-129.

35. Salehi M (2007). Reasonableness of Audit Expectation Gap: Possible Approach to Reducing. J. Audit Pract., 4(3): 50-59.

36. Salehi, M. (2011). Audit expectation gap: Concept, nature and trace. African Journal of Business Management, $5(21), 8376-8392$.

37. Salehi, M. (2016). Quantifying Audit Expectation Gap: A New approach to Measuring Expectation Gap. Zagreb International Review of Economics and Business, 19(1), 25-44.

38. Salehi, M., Mansoury, A., \& Azary, Z. (2009). Audit independence and expectation gap: Empirical evidences from Iran. International Journal of Economics and Finance, l(1), 165.

39. Shaikh, J. M., \& Talha, M. (2003). Credibility and expectation gap in reporting on uncertainties. Managerial auditing journal, 18(6/7), 517-529.

40. Specht, L. B., \& Sandlin, P. (2011). Auditor perceptions of SAS 99: Do two expectation gaps still exist?. Journal of Applied Business Research (JABR), 20(4).

41. Syamsuddin, Abdul Hamid Habbe \& Mediaty, (2014). The Influences of Ethics, Independence, And Competence on the Quality of An Audit through the Influence of Professional Skepticism in Bpk of South Sulawesi, Central Sulawesi And West Sulawesi. Quest Journals Journal of Research in Business and Management Volume 2 Issue 7 (2014) pp: 08-14 ISSN(Online): 2347-3002 www.questjournals.org. 